\title{
DO LITHUANIAN HIGHER EDUCATION ACCOUNTING PROGRAMS REFLECT ACCOUNTING HARMONIZATION IN THE EU?
}

\author{
Dalia Kaupelyte $^{1}$, Renata Legenzova ${ }^{2}$
}

\begin{abstract}
Financial accounting is undergoing major changes in the EU and worldwide. Great efforts are placed on adoption of high quality accounting standards for listed companies, public sector organizations as well as small and medium business entities. Being a member of the EU Lithuania is in compliance with the EU incentives in de jure accounting harmonization; however de facto situation in Lithuania is not adequately assessed. One of accounting harmonization related questions is whether Lithuanian higher education provides labor market with market-needs oriented accounting professionals.

The objective of this article is to assess if Lithuanian higher education programs in accounting field is in compliance with EU accounting harmonization outcomes. We analyze if graduates of Accounting programs from Lithuanian Higher Education Institutions are trained to work with different sets of accounting standards-International Financial Reporting Standards (IFRS) and Public Sector Accounting Standards that were adopted in Lithuania as a part of accounting harmonization incentives. To conduct an assessment of research methods by case analysis, comparative analysis has been deployed. We assessed programs goals, learning outcomes and course curriculum of Professional Bachelor, Bachelor and Master level programs in Lithuanian universities and colleges.

Results of the research revealed that de jure accounting harmonization is reflected in Lithuanian higher education Accounting programs. Accounting for listed companies (required to use International Financial Reporting Standards) is given little importance in Lithuanian Accounting programs. According to the analysis of the learning outcomes, graduates of the Accounting programs in Lithuania have a broad profile, but would not be able to work independently with International Financial Reporting Standards. On the other hand, even if regulation of public sector accounting was enforced later, it is included in number of analyzed programs. A number of Professional Bachelor's programs even offer specialization in this area. Results of the research allow us to conclude that colleges have their niche in preparing accounting specialist for local labor market and their positioning is relatively strong, concerning public sector accounting. Meanwhile first and second level universities' programs could be strengthened toward international accounting to provide labor market with professionals in this area.
\end{abstract}

JEL Classification Number: A22, A23, M41, DOI: http://dx.doi.org/10.12955/cbup.v2.453

Keywords: accounting harmonization, accounting programs, higher education, IFRS, Public Sector Accounting Standards, Lithuania

\section{Introduction}

The aim of accounting education is to achieve high quality of learning outcomes. These learning outcomes have to ensure that a student has both specific and generic knowledge and skills which are in compliance with the needs of labor market. Therefore quality of accounting education is closely linked not only with study process but also with constant consideration of external factors. One of the external factors, which undoubtedly have a great influence on accounting profession, is accounting harmonization and related changes in regulation of financial accounting.

Accounting harmonization in the EU is most often associated with the compulsory adoption of International Financial Reporting standards (IFRS) for all listed companies that consolidate their financial statements staring 2005. It also involved efforts to create a single set of accounting regulation for small and medium companies as well as public sector organizations, convergence with the US GAAP, and other incentives. Most of the EU countries had started accounting harmonization process with similar experience and knowledge, therefore they all faced situation where just a few people (mostly professionals form Big 4 audit companies) knew and understood the new accounting requirements.

\footnotetext{
${ }^{1}$ Dalia Kaupelyte, Vytautas Magnus University, Lithuania, d.kaupelyte@evf.vdu.lt

${ }^{2}$ Renata Legenzova, Vytautas Magnus University, Lithuania, r.legenzova@evf.vdu.lt
} 
Integrating worldwide accepted accounting standards (such as IFRS and Public Sector Accounting Standards) into curriculum of accounting and other business programs became of a great importance to many higher education institutions as graduates of such programs would be more ready to engage in the global labor market.

As a member of the EU, Lithuania is in full compliance with the EU decisions in regards to accounting regulation harmonization (Legenzova, 2007. In short, under the current accounting regulation, Lithuania has three sets of accounting standards: IFRS for listed companies (enforced in 2005), Public Sector Financial accounting and Reporting Standards (PSFARS from 2010) for public sector organizations and national Business Accounting Standards (BAS from 2004) for other business organizations. Historically, BAS were introduced the first, moreover more than $94 \%$ of all Lithuanian companies are small or medium size. Therefore, BAS are the most common set of requirements in Lithuanian accounting education. Analysis of scientific literature revealed that there is no prior research related to the EU accounting harmonization incentives in Lithuanian accounting education. As scope and extent of teaching IFRS and PSFARS in Lithuania is unclear, the objective of this article is to assess if Lithuanian higher education programs in the field of accounting are in compliance with EU accounting harmonization outcomes.

\section{Accounting education-a literature review}

Analysis of scientific literature revealed that accounting education is a broad and well addressed area of scientific research. However, in our opinion, it is also a considerably autonomous from other areas of accounting research. According to Apostoloua, Dormineya, Hassell, \& Watson (2013), a number of scientific journals (e.g. Journal of Accounting Education, Accounting Education: An International Journal, etc.) are devoted just to research in accounting education. However, it has to be noted that all of these journals are American and European-based research and does not comprise a significant volume of all publications. Papers in the other well-known accounting journals (e.g. The Accounting Review, Journal of Accounting Research, etc.) merely scratch the surface of accounting education (Bonnera, Hesfordb, Van der Stedea, \& Young, 2006).

Over the years, a number of studies have been conducted with the goal of reviewing and classifying papers in accounting education. Apostolou et al. (2013, 2010) conducted an exhaustive analysis of journals in six accounting education literature over multiple periods (2010-2012, 2006-2009 and earlier). The authors classified all the empirical research, descriptive articles and educational cases into four broad categories: 1) related to curriculum, content and assurance of learning outcomes; 2) related to educational technology; 3) related to faculty issues; and 4) related to students. It has to be noted that papers related to issues of accounting harmonization (teaching of IFRS to be more precise) has been reviewed among others in a first category. Apostolou et al. (2013) concluded that during the period of 2010-2012 a number of IFRS related research significantly increased in comparison to previous periods.

Analysis of accounting education research related to accounting harmonization (i.e. changes in accounting regulation, adoption of IFRS, convergence of IFRS and US GAAP, adoption of public sector accounting standards, new EU accounting directive, etc.) revealed that most IFRS related issues are somewhat addressed in accounting education research. Most of such research is conducted in the US environment and covers issues related to scope and content of IFRS taught at various study levels and study programs (Alon, 2012; Allen, Mastilak, Randolph, \& Weickgenannt, 2012; Jermakowicz \& Hayes, 2011). Some IFRS related accounting education research has been conducted in Brazil (Lopes, 2011), South Africa (Coetzee \& Schmulian, 2012), and Russia (Preobragenskaya, McGee, 2003). However, our literature 
review did not reveal any research about situation in the EU or its member states over the past five years. Moreover, we did not find any comparative research across countries or periods as well. Literature analysis also revealed some articles related to public sector accounting education (Sciulli \& Sims, 2008; Krah \& Aweh, 2013); however, we have to agree with analyzed authors that scientific research in this area is very limited.

\section{Methodology}

The objective of this research is to assess the compliance of Lithuanian higher education programs in accounting field to EU accounting harmonization outcomes. We analyze if graduates of accounting programs of Lithuanian higher education institutions are trained to work with different sets of accounting standards-International Financial Reporting Standards (IFRS) for listed companies and Public Sector Financial accounting and Reporting Standards (PSFARS) for public sector companies that were adopted in Lithuania as a part of accounting harmonization incentives. To conduct research methods assessment of case analysis, comparative analysis has been deployed. We analyzed specializations Lithuanian Accounting programs, those their learning outcomes that are related to IFRS and PSFARS, also subjects on IFRS and PSFARS on the Bachelor and Master level.

At the end of 2013, there were 24 colleges (13 state and 11 private) and 23 universities (14 state and nine private) in Lithuania. The initial scope of this research was 17 college Professional Bachelor level ( $1^{\text {st }}$ level), as well as three university Bachelor level ( $1^{\text {st }}$ level) and four university Master level ( $2^{\text {nd }}$ level) study programs in the field of accounting. All the analyzed accounting programs are registered in the Register of Study and Teaching Programs in Lithuania as of the beginning of year 2014. It should be noted that specifics of Professional Bachelor's programs in Lithuanian colleges are orientated toward practical skills development for local market. Having selected data for the research, two college Professional Bachelor's programs were excluded, as they replicate existing programs in other branch of the same college. One college does not provide program description, therefore, 14 college programs remained in the analysis. Research was conducted in three steps:

- $\mathbf{1}^{\text {st }}$ step: Analysis of programs specializations, seeking to determine whether colleges or universities offer programs specializations in IFRS, Public Sector Financial Accounting and Reporting Standards (PSFARS) or other.

- $\quad \mathbf{2}^{\text {nd }}$ step: Analysis of programs learning outcomes, in order to determine if the learning outcomes of programs are directly or indirectly related to IFRS or PSFARS.

- $\quad 3^{\text {rd }}$ step: Analysis of study subjects offered on IFRS or PSFARS.

Research was based on the information provided on the websites of Higher Education Institutions. To conduct an assessment of the research method, a comparative analysis has been deployed.

\section{Results of the research}

Analysis of the programs specializations show that some of the Higher Education Institutions have specialization in PSFARS, but none of them in IFRS (see Table 1).

Results of analysis revealed that six colleges offer at least one specialization. None of the analyzed colleges offers specialization in IFRS, but five of them offer specialization in PSFARS. Moreover, nine other specializations in different areas such as accounting in commercial organizations, production accounting, managerial accounting and audit, financial accounting, accounting in agriculture, accounting 
in credit and financial institutions, are offered by six colleges with specialization in accounting program. However, none of the analyzed universities provided specialization in IFRS or PSFARS and two universities offered three other specializations in their Bachelor's programs: audit, financial accounting and reporting, and finance.

Table 1: Specializations in Accounting Programs of Lithuanian Higher Education Institutions
\begin{tabular}{|c|c|c|c|}
\hline & \multicolumn{3}{|c|}{ Programs specializations } \\
\hline Study programs level & IFRS & PSFARS & Other \\
\hline Universities & & 0 & 3 \\
\hline$\bullet \quad$ Bachelor level & 0 & 0 & 0 \\
\hline$\bullet \quad$ Master level & 0 & & 9 \\
\hline Colleges & & 5 & \\
\hline$\bullet \quad$ Professional Bachelor level & 0 & & \\
\hline
\end{tabular}

Source: Authors

Analysis of learning outcomes showed that although there is no specialization in IFRS in Lithuanian Higher Education Institutions, some of them directly or indirectly declared goals to develop competencies in these standards (Table 2). This may indicate that Lithuanian graduates may have some knowledge of IFRS. A situation with PSFARS is similar. Data analysis also indicated that Lithuanian colleges should place more efforts on development of learning outcomes as they are incomplete and unclear.

Table 2: Learning outcomes related to IFRS or PSFARS in Accounting Programs of Lithuanian Higher Education Institutions

\begin{tabular}{|l|c|c|c|c|}
\hline & $\begin{array}{c}\text { Learning outcomes directly } \\
\text { related to: }\end{array}$ & \multicolumn{2}{c|}{$\begin{array}{c}\text { Learning outcomes } \\
\text { indirectly related to: }\end{array}$} \\
\hline Study programs level & IFRS & PSFARS & IFRS & PSFARS \\
\hline Universities & & & & \\
\hline$\bullet \quad$ Bachelor level & 1 & 4 & 1 & 1 \\
\hline$\bullet \quad$ Master level & 2 & 0 & 1 & 2 \\
\hline Colleges & & & & \\
\hline$\bullet \quad$ Professional Bachelor level & 7 & 6 & 3 & 7 \\
\hline Source: Authors & \multicolumn{3}{|l}{} \\
\hline
\end{tabular}

One of the colleges did not provide learning outcomes and was excluded from the analysis; thus, 13 colleges were covered in the analysis. Six learning outcomes on PSFARS were from Professional Bachelor level and four learning outcomes came from one specialized program, "Public Sector and Business Financial Accounting" in "Kolpingo kolegija." At Bachelor level, only Kaunas Technology University provides two learning outcomes directly related to IFRS and PSFARS. Mykolas Riomeris University provides two learning outcomes indirectly related to IFRS and PSFARS. Aleksandras Stulginskis University provides three learning outcomes related to PSFARS and none related to IFRS. 
Analysis of study subjects at both Master and Bachelor level studies is consistent with previous resultsonly a few Lithuanian Higher Education Institutions (Table 3) teach IFRS and PSFARS, as separate study subjects. Surprisingly, only one university offers IFRS-based course (Consolidated Financial Accounting) in Master level studies and none in PSFARS. At university Bachelor level, two universities (Kaunas Technology University and Mykolas Riomeris University) offer three study subjects related to IFRS ( 2 - International Accounting and 1 - Consolidated Financial Accounting). All three universities with accounting programs at Bachelor level offer a separate PSFARS subject.

\begin{tabular}{|c|c|c|}
\hline \multirow[b]{2}{*}{ Study programs level } & \multicolumn{2}{|c|}{ Study subjects on: } \\
\hline & IFRS & PSFARS \\
\hline \multicolumn{3}{|l|}{ Universities } \\
\hline - $\quad$ Bachelor level & 3 & 3 \\
\hline - $\quad$ Master level & 1 & 0 \\
\hline \multicolumn{3}{|l|}{ Colleges } \\
\hline - Professional Bachelor level & 2 & 12 \\
\hline Source: Authors & & \\
\hline
\end{tabular}

Out of 15, only two colleges offer separate subjects on IFRS (one of them under the name of International Accounting). As Table 3 shows, a total of PSFARS-related, 12 subjects are offered by six analyzed colleges. It has to be noted that such a high number of PSFARS subject is influenced by three colleges that each offers three subjects on PSFARS in their specialization.

\section{Conclusion}

Accounting harmonization is gaining importance around the world. As a member of the EU, Lithuania complies with the EU accounting harmonization incentives. Under current regulation, three sets of accounting standards-IFRS, Business Accounting Standards and Public Sector Financial Accounting and Reporting Standards are enforced in Lithuania for different types of organizations.

Our review of publications in accounting education allows a conclusion that the research of accounting education is limited and autonomous from other areas of accounting harmonization. Such research has a strong orientation toward the study process and its participants. Curriculum and content of accounting programs in the context of accounting harmonization and their comparison over the time and across the countries are insufficient. Finally, no prior research in Lithuania has been conducted previously.

Results of Lithuanian accounting programs analysis revealed that IFRS is given a very little importance in Lithuania. None of the analyzed universities or colleges offers a specialization in IFRS. Only a few accounting programs in Lithuania identify IFRS-related learning outcomes and offer them as separate subjects. This leads to the conclusion that graduates of accounting programs do not have sufficient knowledge and skills to work with IFRS. With a small economy, Lithuania should focus more on global labor market and needs of international business. Therefore, universities should strengthen their accounting programs toward International Accounting and IFRS. 
The results of our research showed greater presence of PSFARS in Lithuanian higher education even though these standards were adopted much later than IFRS. Specialization in PSFARS is already offered by a number of colleges, but universities only offer a few subjects in this area. Lithuanian colleges have already created some competitive advantage in teaching PSFARS and should further develop this area.

\section{References}

Alon, A. (2012). The IFRS question. To adopt or not? Advances in Accounting Education, 13, 405-423.

Allen, J., Mastilak, M., Randolph, D., \& Weickgenannt, A. (2012). Advances in Accounting Education, 13, 315 - 347

Apostoloua, B., Dormineya, J., Hassell, J., \& Watson, S. (2013, June). Accounting education literature review (2010-2012). Journal of Accounting Education, 31(2), 107-161. doi: 10.1016/j.jaccedu.2013.03.001

Apostoloua, B., Hassellb, J., Rebelec, J., \& Watson, S. (2010, September). Accounting education literature review (2006-2009). Journal of Accounting Education, 28(3-4), 145-197. doi: 10.1016/j.jaccedu.2011.08.001

Bonnera, S., Hesfordb, J., Van der Stedea, W., \& Young, S. (2006, October). The most influential journals in academic accounting, Accounting, Organizations and Society, 31(7), 663-685. doi: 10.1016/j.aos.2005.06.003

Coetzee, S., \& Schmulian, A. (2012). A Critical Analysis of the Pedagogical approach employed in an Introductory course to IFRS. Issues in accounting Education, 27(1), 83-100.

Jermakowitz, E., \& Hayes, R. (2011). Framework-based teaching of IFRS: the Case of Deutsche Bank. Accounting Education: An International Journal, 20(4), 387-397.

Krah, R., \& Aweh, F. (2013). Public Sector Accounting Education: A Neglected Element of Public Financial Management Reform in Ghana. International Journal of Financial Management, 13(1), 36-51.

Legenzova, R. (2007). Accounting Regulation Changes in Lithuania: An Assessment. doi: 10.2139/ssrn.1021192

Lopes, A. B., (2011). Teaching IFRS in Brasil: News from the front. Accounting Education: An International Journal, 20(4), 339-347.

Preobragenskaya, G., \& McGee, R. (2003). Accounting Education in a Transition Economy: A Case Study of Russian Universities. Retrieved from, http://ssrn.com/abstract=459361

Sciulli, N., \& Sims, R. (2008). Public sector accounting education in Australian universities: Obstacles and opportunities. Asian Review of Accounting, 16(3), 246-262. doi: 10.1108/13217340810906690 